\title{
Research Note:
}

\section{Mapping Positive Change in Manitoba Colony, Chihuahua, Mexico}

\author{
Gracia Schlabach $^{1}$ \\ Lyndonville New Order Amish Church
}

\begin{abstract}
While working in Manitoba Colony, Mexico, as a teacher under Old Colony Mennonite Support from 2009 to 2014, I gathered data about the community from conversations and periodicals such as Kurze Nachrichten aus Mexico, Deutsch-Mexikanische Rundshau, Das Blatt, and Die

Mennonitische Post. This information shows both changing demographics and positive change that stems from improved literacy.
\end{abstract}

\section{Keywords}

Colony; Dorf(village); Campo (village); Mennonite Central Committee; Old Colony Mennonite Support; Dorf school; committee school

\section{Introduction}

The Old Colony Mennonites trace their beginnings to The Netherlands, then to Ukraine, and Canada. From 1922 to 1925, more than 5,000 Mennonites from Canada settled in central Chihuahua state after being granted special privileges by the Mexican government - exemption from military service and freedom in all matters of education and worship. Here, they established a thriving agricultural community (population of ca. 15,000 in 2010), but they were not exempt from hardships. The early 1990s were particularly difficult due to severe drought.

In 1995, a watershed event took place when a group of Amish from the United States toured Manitoba Colony upon the invitation of Mennonite Central Committee (MCC) who had a longstanding presence in the colony and saw the possibility of these two groups - similar in conservative tradition-working together for economic and educational improvement. Old Colony Mennonite Support (OCMS) was formed by Amish to support a model dairy and a cheese house, and some years later, an intense school project. Since 2000, Amish and Old Order Mennonite teachers from the United States have been working in Manitoba Colony schools (Old Colony Mennonite Support 2011).

\section{Colony Layout}

Manitoba Colony residents live in either organized Dorfs (villages) or along the northsouth connecting highway, officially named Corredor Commercial Manitoba in 2013. Villages 
have a dual identity with both a traditional German name and a Spanish Campo number. Campo numbers begin south of Cuauhtémoc and ascend northward on the west side of the highway and southward on the east side. Places along the highway are identified by kilometer marks, which begin just north of Cuauhtémoc and ascend northward to Alvaro Obregón (Rubio).

\section{School Developments}

In a typical Old Colony Dorf school, the children of a given village - often from 20 to 30 but sometimes as many as 60 or 80 - learn by rote as a group with a minimum of books: the Bible, a songbook, a catechism, and a primer. When the Dorf school system in Manitoba Colony caused a growing concern and dissatisfaction among colony leaders in the mid-1990s, a School Committee (officially, Comité Para-Mejoramiento de la Educación Colonia Manitoba) of eight visionary Old Colony men was formed in 1998. Amish teachers first arrived in 2000. They assisted at the fledgling schools at Gnadenthal and Lowefarm already operating under the guidance of this Committee. These schools had grade levels and used textbooks for standard school subjects but still upheld the religious training so essential to Old Colony culture.

This new system met with much skepticism, even opposition, at first, and several Dorf schools returned to their previous status after several terms. Meanwhile, the larger schools built expressly for the Committee system have grown to a combined enrollment of 700 students in 2012, and nearly 1,000 in 2016 or half of Manitoba Colony's school-age children. The School Committee now consists of 12 members serving seven-year terms.

The influence of these Committee schools has a magnitude far beyond better literacy. According to this quote from an anonymous Manitoba Colony resident:

Früher wurde hier in unserer Kolonie immer gesagt, dass Jugendliche hochnäsig, frech und respektlos warden, wenn sie zu viel lernen. Ich sehe aber das gegenteil. Seitdem unsere Schulen sich hier verbessert haben, sieht man viel weniger Jugendliche auf den Straßen, die dort stören, streiten und leider zu oft mit Alkohol und Drogen spielen. Die besseren Schule haben eine Gute Wende gebracht und ich wünschte, mehr Personen in den Kolonien würden dieses erkennen. (Die Mennonitsche Post, Nov. 22, 2013)

[Earlier, it was always said that youth become proud, bold, and disrespectful when they have too much education, but I observe the opposite. Since our schools have been improved, there are fewer youth hanging out on the streets to cause a disturbance and to fight, or unfortunately, too often experiment with drugs and alcohol. The improved schools have brought a positive change and I wish more people in the colony would recognize it.]

The supervised youth activities Abendschule (weekly evening classes) and Jugendtreffen (youth meeting) have also played a large role in positive change. Abendschule, which began about 2000, was intended as an opportunity for teens to practice their catechism and some school 
subjects. Each teacher determines the pattern of his Abendschule. Some follow a more traditional Dorf school pattern, while others are held at Committee schools.

Jugendtreffen, a more informal affair with singing, volleyball, and other games, and snack, was first held at Gnadenthal School in 2010, usually once a month on Sunday afternoon. It moved to Lowefarm in 2014 when a gimnasio, or Mehrzweckhalle (multipurpose building) was constructed. The following year, a second one was built in Kronsgart, and plans are underway for a third in Tochfeld. Besides Jugendtreffen Wednesday evening and Sunday afternoon, these buildings also provide space for family night on Friday evening and school events such as programs and benefit sales.

\section{Church Growth}

The colony is divided north and south with two groups of ordained men who serve their respective side. In 2016, each side had seven church houses. Each side also had a senior and a newly ordained Ältester (bishop), eight or nine ministers, and two deacons. The ministers, including the Ältester, take turns to preach in the order they were ordained, one per Sunday per church house, making a rotation among all the church houses of their side. The deacons do not preach. Both of the Ältester and the eight ministers were ordained since 2011, with six of them having active roles in education, from Dorf schools or Abendschule teacher to Committee member or school principal at a Committee school.

Typically Old Colony children do not attend church services before they are twelve years old. Since about 2010, however, many preschool and school-age children in Manitoba Colony attend Sonntags Schule (Sunday school). Several factors have contributed to this development. First, in the last decade, at least half of the original church houses have been replaced by a larger building on the same grounds, making the smaller, older building available for another purpose. Second, the growing educational zeal has extended itself to meaningful Sunday forenoon activities for the children, initially organized by persons who were also active in the Committee schools. Sunday school had its beginning in Kronsgart and other south end villages, but by 2016, Sunday school was also being conducted as far north as Kronsthal.

Another recent development is Jugendunterricht (weekly instruction class for youth) prior to baptism, which first took place at the Gnadenhof church in 2013. The following year, the class was divided with a second location, the new Neureinfeld church. Ministers conduct the class using Katechismus Erklarung (The Catechism Explained) books.

\section{Endnote and Reference}

${ }^{1}$ Contact information: Gracia Schlabach, 2784 Murdock Rd., Medina, NY 14103.

Old Colony Mennonite Support. 2011. Called to Mexico: Bringing Hope and Literacy to the Old Colony Mennonites. Nappanee, IN: Old Colony Mennonite Support. 


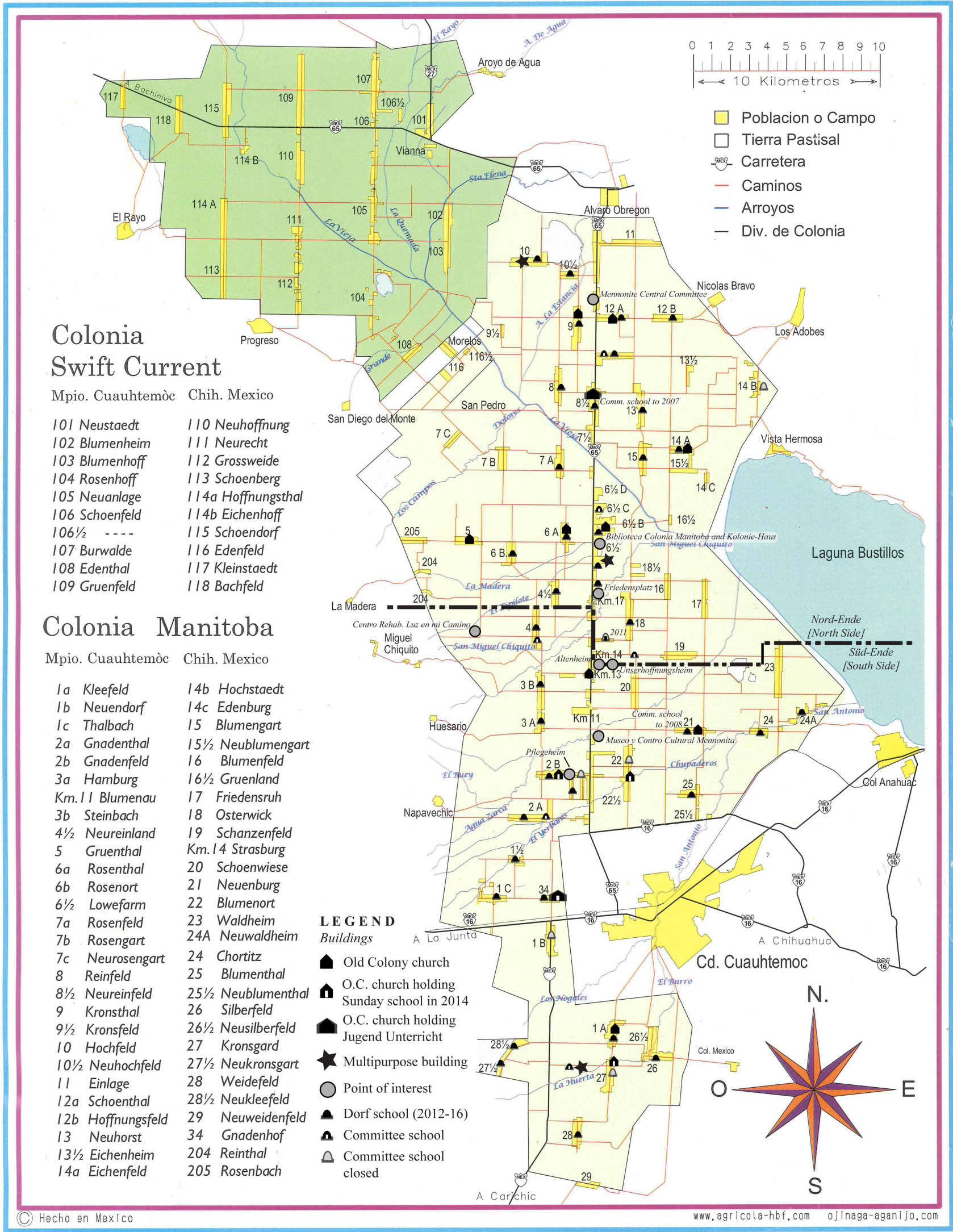

"Legend" icons added to base map. Base map used with permission. ORuben Giesbrecht E.. 